\title{
Helping populism win? Social media use, filter bubbles, and support for populist presidential candidates in the 2016 US election campaign
}

Jacob Groshek \& Karolina Koc-Michalska

To cite this article: Jacob Groshek \& Karolina Koc-Michalska (2017): Helping populism win? Social media use, filter bubbles, and support for populist presidential candidates in the 2016 US election campaign, Information, Communication \& Society, DOI: 10.1080/1369118X.2017.1329334

\begin{abstract}
Undoubtedly, populist political candidates from the right and the left, including Donald Trump and Bernie Sanders changed the tenor and direction of the 2016 presidential contest in the US. Much like Barack Obama's electoral successes that were credited at least in part to his savvy social media campaigning in 2008 and 2012, since Trump's victory, the notion that social media "helped him win" has been revitalized, even by Trump himself (McCormick, 2016a). This study therefore explores citizen support for populist and establishment candidates across the ideological spectrum in the US to specifically examine if using social media was related to an increased likelihood of supporting populist presidential political candidates, including Trump. Differing forms of active, passive, and uncivil social media were taken into account and the findings suggest active social media use for politics was actually related to less support for Republican populists, such as Trump, but that forms of both passive or uncivil social media use were linked to an increase in the likelihood of support to a level roughly equivalent to that of the traditional television viewing. These patterns are almost the inverse of support for Democratic populists, in this case namely Sanders.
\end{abstract}

Keywords: Populism, social media, elections, president, campaigns, Trump 
Contemporarily, it is all but taken for granted that social media is part and parcel of any presidential campaign in developed nations (Xenos, Vromen, \& Loader, 2014). Considering the 2016 presidential election in the US, it was clear even before the election was called for Donald Trump that populist political candidates from the right and the left, including Trump and Bernie Sanders in particular, but also other non-establishment actors such as Ben Carson, had a profound resonance with American voters that reshaped the nature of the campaign as it was experienced by voters.

A related - and growing - body of scholarship has similarly explored, and in many instances found evidence of an ideological horseshoe that aligns certain features of left-wing and ring-wing populism, particularly in the European context (van Elsas, Hakhverdian, \& van der Brug, 2016a). Still, much of the work on this topic is just now starting to identify those linkages in digital trace data of social media content (Engesser, Ernst, Esser, \& Büchel, 2016), and American political contests with multiple candidates, such as presidential primaries, have largely been overlooked because of the stable two-party system in the US (Groshek \& Engelbert, 2013). This study thus proceeds from the broad vantage point of examining whether or not there is a similar ideological horseshoe of citizen support for populist politicians in the US that has been observed elsewhere, and the extent to which support for populist candidates is related to social media use.

Of course, the 2016 US presidential campaign experienced a wide range of unprecedented issues that included, among others, widely circulated "fake news" stories (Silverman, 2016), the increased prominence of populist rhetoric among candidates (Oliver \& Rahn, 2016), and the pivotal role that social media seemed to play in sustaining support for populist candidates among voters (Kriesi, 2014; Tufecki, 2016). In the aftermath of the Election Day that brought the US presidency to Trump, media coverage around the world registered surprise at the unexpected success of the populist right-wing candidate that often 
had disputes within the Republican Party leadership itself. One explanatory narrative that quickly emerged was that social media, by acting as portals of shared information determined to be sought (algorithmically or otherwise) by users, may have helped Trump win by cultivating ideological filter bubbles that lacked cross-cutting information (Baer, 2016; McCormick, 2016b; Newton, 2016; Pariser, 2011).

Indeed, the days and weeks after the election were marked by regular coverage of social media propagating "fake" campaign news (Parkinson, 2016; Welch, 2016), creating the psychological profiles for targeting certain voters (McKenzie, 2016), intensifying ideologically charged or partisan feelings (Herrman, 2016), or even influencing the election outcome itself (Isaac, 2016; BBC Trending, 2016; Hooton, 2016; Isaac \& Ember, 2016; Lapowksy, 2016). Further, in the months since Trump took office, the argumentation over fake news has only intensified, as have analyses suggesting tightly linked chains of ideologically-shaped information flows and filter bubbles where individuals intentionally or unintentionally self-select into media coverage that is ideologically monolithic, patently false, or a combination of both (Benkler, Faris, Roberts, \& Zuckerman, 2017).

It can therefore easily observed that the political landscape of the 2016 elections in the US was atypical and the results took pundits and pollsters by surprise (Bartels, 2016; Lapowsky, 2016). And while Oliver and Rahn (2016) found a "representation gap" stemming from concurrent frustration among American citizens that helped to stimulate the demand for populist candidates (Spruyt, Keppens, \& Van Droogenbroeck, 2016), we expand this study further to examine exactly how differing forms of social media use did (or did not) contribute to supporting populist political candidates from both the left and the right, and in so doing make a vital contribution to the academic literature on the topic as well as to public understanding and debate of this pressing issue. 
Thus, we review populism in the framework of the 2016 US election, and based on study by Oliver and Rahn (2016) place the rhetoric of candidates along a continuum of populism, regardless of political party affiliation. We continue to outline how previous studies have connected citizens' use of differing forms of active, passive, and uncivil social media use to other political considerations, including engagement, knowledge, network heterogeneity and support for populist political actors while controlling for a wide range of factors and characteristics.

\section{Reviewing Populism as a Political Phenomenon}

Populism is a highly discussed concept in the recent literature, especially when eclectic (left or right wing) political approaches are named with the same word (Krastev, 2007). In establishing a working baseline, Moffitt and Tormey (2014) distinguish four different current concepts of populism (as ideology, as political logic, as discourse and as strategy) and as counterpoint they develop the approach of populism as a 'political style' (p. 386). Earlier works on populism underlined style as an element of populism, however, most focused mainly on rhetoric and discursive parts of political communication referring to people in an us-them framework (Jagers \& Walgrave, 2007).

Thus, populism-as-a-style ascended notably with the (post) modernization of society, declining of traditional ideological and party cleavages, and alienation from traditional politics that took place at the same time as the mediatization of politics, which raised the gigantic spectacle over substantive aspects (Moffitt \& Tormey, 2014). Modern populism is thus defined by Moffitt and Tormey as "political style as the repertoires of performance that are used to create political relations" (2014, p. 387). Further, (Trudel, 2016) claims after JeanPaul Sartre that the populism of American presidential candidates, and in 2016 most notably Trump, relieved certain groups of citizens from an 'anxiety of freedom' and responsibility for their current social and economic situation. 
This argument squares with the work of Muller (2016), who identified three necessary conditions for populism to exist: anti-elitism (going beyond the simple opposition toward incumbent parties), antipluralism (with moral justification of the 'us-them' distinction within society), and finally the adequate socioeconomic situation with large gaps between groups. Yet much of the recent work explaining the popularity of the populism concentrates on different characteristics of the vote choice such as gender or related issues (Gidengil, Hennigar, Blais, \& Nevitte, 2005), leader effects (van der Brug \& Mughan, 2007), stronger populist attitudes among voters who decide to vote for populist parties (Akkerman, Mudde, \& Zaslove, 2014), or psychological dispositions such as the effect of agreeableness (Bakker, Rooduijn, \& Schumacher, 2016). Along these lines, Spruyt, Keppens \& Van Droogenbroeck (2016) found the lack of political efficacy, feeling of belonging to the deprived groups, and anomie - from Durkheim's observations on the detraditionalization of society - were strong predictors of support for populism.

Yet missing from these approaches is an understanding of the role of media (Ernst, Engesser, \& Esser, 2016) - and particularly social media - in the process of vote choice, and especially in supporting more populist political candidates. Somewhat ironically, this sort of research seems to be especially necessary to develop such arguments as those previously discussed; namely, the mediatization of national social units that are at least partly responsible for the rise of non-traditional candidates and the creation of ideological filter bubbles via content shared on social media (Benkler et al., 2017; Strandberg, 2013).

To this point, in a longitudinal approach, Rooduijn (2014) studied populist messaging that was diffused beyond political parties by concentrating on newspaper coverage. In that study, he traced how populist public debate in both elite and tabloid outlets grew over time. Similarly, Koopmans and Muis (2009) found strong evidence on the relationship between the visibility of arguments in press coverage from right-wing populist and their electoral success. 
With regard to newer forms of emerging social media, Miconi (2015) illustrated the way in which the rising populist group, specifically the Five Star Movement in Italy, managed its web communication strategy to rise and sustain its position on Italian political scene.

Likewise, Ceron and d'Adda (2016) reported that negative campaigning produced by candidates and received from others via social media such as Twitter, as well as distributive promises, have had positive effects on the vote share. Engesser and colleagues (2016) further indicated in cross-country analysis that "social media give the populist actors the freedom to articulate their ideology and spread their messages". Studies on the role of social media in gaining popularity by populists are especially important when considering that populist-voters can also be the 'last minute' voters who decide shortly before casting the vote for whom to vote, and who may be most strongly influenced by the campaign messages run by candidates or media outlets (Fawzi, Obermaier, \& Reinemann, 2016).

Altogether, research on the impact of mobile and social media usage on political participation, engagement, talk, and efficacy are well developed in communication literature (cf., Boulianne, 2009, 2015; Skoric, Zhu, Goh, \& Pang, 2016), yet the impact of emerging media directly on the vote choice is rarely studied. In one notable exception, Kruikemeier and colleagues (2014) found that citizens using certain websites facilitated increased forms of political engagement that may connect to voting on election day - yet even then, the reported effect was weaker or inverse for passive rather than for more active forms of political internet use.

Populism and filter bubbles in \#election2016

Early research on populism during the US 2016 presidential elections (Oliver \& Rahn, 2016) has indicated that as more traditional or otherwise established political candidates cultivated populist support, it was primarily through an emphasis on one form of populist 
communication or another (e.g., Sanders on anti-elitism, Ted Cruz's mistrust in experts, or Marco Rubio's pan-national affiliation). Yet Trump, and to a lesser extent Ben Carson, were obvious political outsiders that never held political office, and both employed varied forms of populist communication that included, but were not limited to, an array of rhetoric that demonstrated anti-elitism, expert mistrust, we-they dimensionality, and nationalistic appeals.

In addition, recent work by Benkler, Faris, Roberts and Zuckerman (2017) found that in "over 1.25 million stories published online between April 1, 2015 and Election Day shows that a right-wing media network anchored around Breitbart developed as a distinct and insulated media system, using social media as a backbone to transmit a hyper-partisan perspective to the world" (p. 1). They continue to argue that this media sphere actually set the overall media agenda to the extent that the outcome of the election was influenced, and that the preponderance of misinformation and so-called fake news circulated so widely (Silverman, 2016) that it may well have shaped the viewpoints and decision-making of voters.

The purpose of this article is thus to evaluate the role that the usage of social media played in influencing voters' support for certain candidates, specifically evaluated along the lines of populist leanings, while still taking other factors into account. To do so, this study used nationally representative survey data from an early stage of the 2016 campaign, approximately two months before the primaries began.

In order to examine citizen support for populist candidates, we selected candidates that were intensively campaigning at the time of start of the presidential primaries on February 1, 2016 and this study considered "the seven top presidential hopefuls" identified by Oliver and Rahn (2016, p. 192) in their study. Those findings provide us an objective baseline of the populist leanings for five Republican Party candidates - Kasich, Cruz, Rubio, Carson, and Trump as well as two Democratic Party candidates - Clinton and Sanders. Stated more explicitly, Oliver and Rahn (2016) ranked each of these seven candidates on a populism scale 
based on the rhetoric they used while campaigning, and we employ that ranking to categorize candidate support among our respondents for more establishment or populist candidates ${ }^{1}$ and we examine forms of social media use in relation to support for each of the candidates.

\section{Active, passive and uncivil social media use}

Whereas previous research has generally examined the use of social media as it relates to differing forms of political participation (Gil de Zúñiga, Garcia-Perdomo, \& McGregor, 2015) or political knowledge (Groshek \& Dimitrova, 2013), this study breaks new ground by examining how differing forms of social media use may relate to increased support for populist political candidates from the ideological left and right.

Along these lines, Svensson and Klinger (2015) claimed that the social media logic assumes the coproduction and interactivity, while passive receiving of (filtered) messages originates rather from the traditional media environment. Other research has distinguished active (interactive, two-way communication or creative) and passive (reading, viewing or consuming) engagement or usage within the social media sphere (Bakker \& de Vreese, 2011) and found negative relationships to knowledge (Dimitrova, Shehata, Strömbäck, \& Nord, 2014) but positive and directional relationships on different forms of political participation (Kruikemeier et al., 2014).

Similar marketing studies have found the different effects of active and passive functionality within social media, with active use positively influencing self- and socialidentity expression (Pagani, Hofacker, \& Goldsmith, 2011). Also, in an experimental study, Maruyama and colleagues (2014) reported that “participants' average feeling and recall toward the candidates did not depend on Twitter activity, but Twitter activity did matter for

\footnotetext{
${ }^{1}$ Details follow in the methods section, but on this scale Kasich (.24) was determined to be "least populist" by Oliver and Rahn (2016), followed by Cruz (.25), Rubio (.49), Clinton (.58), Carson (.60), Trump (.66), and Sanders (1.22).
} 
vote choice," and that the immediate effect was especially strong during the 2012 Senate debate. Additional research has suggested that different social media platforms may facilitate more uncivil behavior, particularly on mobile devices (Hmielowski, Hutchens, \& Cicchirillo, 2014; Groshek \& Cutino, 2016) and may reduce politeness (Halpern \& Gibbs, 2013) or the willingness to open to others (Colleoni, Rozza, \& Arvidsson, 2014).

In the light of those findings, with differing effects for various forms of active and passive social media use on political engagement, as well as affordances of social media platforms that tend towards increased incivility, we aim to understand further those phenomena by examining relationships that may also exist as support for populist candidates. Thus, we begin by posing the following research questions:

RQ1: Did more active, passive, or uncivil social media usage relate to supporting a specific presidential candidate?

RQ2: To what extent do higher levels of social media activity, passivity, and incivility relate to a general preference for populism?

Continuing, our study also addresses the relationship between the formation of filter bubbles and the decrease in cross cutting information and network diversity that has been linked to social media use (Bakshy, Messing, \& Adamic, 2015; Flaxman, Goel, \& Rao, 2013). This follows previous work on the impact of acquaintances and non-cohesive groups in influencing individual-level support demonstrated by Vezzoni and Mancosu (2016) in their analysis of support for the populist Five Star Movement in Italy. Here, in testing a position that rose quickly to prominence after the election (Baer, 2016; El-Bermawy, 2016; Strandberg, 2013) in the final research question, we examine the extent to which filter bubbles - as signaled by decreased network heterogeneity - may have boosted support for populist political candidates from the left and the right. 
RQ3: Was support for populist candidates related to having less heterogeneous social networks online and offline?

\section{Methods}

We gathered data for this study from 16 November to 3 December 2015, and included responses from 1,105 opt-in Qualtrics panel respondents online. Generally speaking, this sample closely matches demographic features of the US population, though limitations on generalizability remain for online samples (cf., AAPOR 2010; Peifer \& Garrett, 2014). Nonetheless, similar stratified online quota samples are regularly used with inferential statistics in the field to generalize to national-level populations (Gil de Zúñiga, GarciaPerdomo, \& McGregor, 2015).

This study proceeded by developing two key dependent variables that model support for individual presidential candidates and populism in aggregate. We do this using a unique combination of survey data on voter support and combining those expressions of support with ratings of candidates' level of populism that is based on previous work by Oliver and Rahn (2016). Their scale of populist rhetoric among candidates placed seven U.S. presidential candidates on a continuum of centrist, establishment rhetoric to highly populist, antiestablishment speech patterns ${ }^{2}$ and we use that ranking to determine the extent to which survey respondents support individual populist candidates as well as populist candidates in general, regardless of their political affiliation.

Candidates' level of populism: As reported by Oliver and Rahn (2016) among Republicans, the scale of populism was lowest for Kasich (.24) and then increased to Cruz (.25), Rubio (.49), Carson (.60), and Trump (.66). Among the two Democrats analyzed by

\footnotetext{
${ }^{2}$ Please see the original article by Oliver and Rahn (2016) for their methodology, which was based on an empirical examination of the syntax and language of each candidate to arrive at a statistically-computed level of populism for each candidate from a dictionary of terms and keywords.
} 
Oliver and Rahn (2016), Clinton (.58) notably more centrist and pro-establishment than Sanders (1.22). Support for candidates are ranked on this scale from least to most populist according to their level of populist rhetoric as outlined by Oliver and Rahn (2016), with separate rankings for Republicans and Democrats in the study reported here because it was possible to in the survey to choose one candidate per party.

Ordered logistic regressions were run separately to model support for Democratic ( $\mathrm{N}=887)$ and Republican $(\mathrm{N}=660)$ populism. Altogether, this variable operationalizes general populist preference for candidates from both the left and the right, and thereby conceptually examines the notion of an ideological horseshoe amongst populist supporters.

Candidate support: Here, support for each individual candidate was set as a zero-one binary. As respondents were required in the survey to indicate which candidate they would support for both Democratic and Republican candidates, this meant all respondents had to register support for one candidate from the left and one from the right. Among the support that was expressed indicated for Democrats, Clinton received $44.8 \%$ and Sanders had 35.5\%. For individual support indicated among Republican candidates, Trump won $24.8 \%$, Carson had $14.4 \%$, Rubio earned 9.2\%, Cruz reached $7.1 \%$ and Kasich acquired $4.3 \%$ of all respondents. To model this individual candidate support, we used a series of logistic regressions.

In keeping with much of the previous work in this area, this study incorporated a range of media-specific independent variables. These multi-item scales were gathered on the same ordinal zero (never) to four (always) level of measurement, and were operationalized as follows for each variable.

Traditional media: This block began with frequency of listening to radio news programs or political talk shows $(\mathrm{M}=.95, \mathrm{SD}=1.01)$. It also included the frequency of 
watching local, national or cable television news $(\mathrm{M}=2.3, \mathrm{SD}=.97)$, reading local or national print newspapers $(\mathrm{M}=1.46, \mathrm{SD}=1.09)$ and using local or national online version of newspapers $(\mathrm{M}=1.36, \mathrm{SD}=1.14)$.

Active social media use: Following work by Kruikemeier et al. (2014), this variable was defined as participating in posting personal experiences related to politics or campaigning, posting or sharing thoughts about current events or politics, posting or sharing photos, videos or audio files that relate to current events or politics, or forwarding someone else's political commentary to other people (M=.88, SD.99, $\alpha=.912)$.

Passive social media use: Building again on Kruikemeier et al. and their 2014 study, this item comprised measures on passively receiving information through social media, namely friending or following a politician or a political advocate and receiving messages or information from a politician or political party $(\mathrm{M}=.79, \mathrm{SD}=1.01, \alpha=.824) .^{3}$

Incivility on social media: This variable was operationalized by combining items on posting aggressive information on social media, and was conceptually derived from (Hmielowski et al., 2014). Specifically, the questions for this item included arguing with someone that has different political views than respondents' own and their self-reported attempts to intentionally initiate online arguments by using hostile or inflammatory words, such as slurs. This was coded into a 0-1 binary, with being uncivil on social media set equal to one, and $41 \%$ having reported doing so at least some of the time.

Time spent on social media: There were two separate items, that measured hours (024) that were spent on Facebook and on Twitter per day, which was not limited to political

\footnotetext{
${ }^{3}$ The correlation between active and passive online activity ranged between 0.6 and 0.7 depending upon whether it was measured by individual support for candidates or populism in aggregate.
} 
uses $\left(\mathrm{M}_{\mathrm{FB}}=2.65, \mathrm{SD}_{\mathrm{FB}}=3.92 ; \mathrm{M}_{\mathrm{TW}}=.13, \mathrm{SD}_{\mathrm{TW}}=.941\right)$. Alternatively only time spent on social media $(\mathrm{M}=3.4, \mathrm{SD}=4.0)$ is indicated for heterogeneity regression.

Filter bubbles: Online and offline network heterogeneity is operationalized by looking at the diversification of political discussion network. Namely, this was a binary variable of having or not discussed politics with people whose political views are different from yours and generally disagree with you, and people from a different race or ethnicity as well as people from a different social class. For offline network (diversified networks had $50 \%$ of respondents, Cronbach's alpha $[\alpha]=.871$ ) for online network (diversified networks had 37\% of respondents, $\alpha=.914)$. The analysis on characteristics predisposing to have more diversified networks are included in Appendix A.

Political antecedents: Here, we took into account political party affiliation, political ideology, and political knowledge. Republicans accounted for $27.7 \%$ of this sample, Democrats were $35.4 \%$, and $33.1 \%$ were Independents (and $6.8 \%$ were 'other' or 'didn't know' their party affiliation). In terms of ideology, from one (very liberal) to seven (very conservative) this sample had a mean of $3.98(\mathrm{SD}=1.83)$. Political knowledge was a summed metric of four basic political knowledge questions, such as identifying the Speaker of the House $(\mathrm{M}=2.49, \mathrm{SD}=1.28)$.

Political efficacy and voting: Internal and external efficacy were based on combined items that ranged from one (very low) to five (very high). Internal efficacy had a mean of $3.27(\mathrm{SD}=0.94, \alpha=.781)$ and external efficacy had a mean of $3.39(\mathrm{SD}=1.13, \alpha=.769)$. Vote frequency from zero (never) to four (always) likewise comprised two items $(\mathrm{M}=2.20$, $\mathrm{SD}=1.61, \alpha=.948)$

Trust and life satisfaction: Trust was based on two questions, specifically, as a rule, people can be trusted, and in most cases, people try to help others. This scale ran from 
strongly disagree to strongly agree on a $1-5$ metric $(\mathrm{M}=3.26 ; \mathrm{SD}=.85 ; \alpha=.761)$. Life satisfaction was based on an additive measure of three questions, which included: in most ways my life is close to my ideal, I am satisfied with my life, and things in my life are difficult (that was reverse coded). Altogether, this scale ran from a minimum of 3 to a maximum of $15(\mathrm{M}=9.4 ; \mathrm{SD}=2.86, \alpha=.779)$.

Socialization variables: This block of items included closeness with others on a 0 to 10 point scale indicating how close one feels towards the others $(M=7.21 \mathrm{SD}=2.7)$. It also included measures of living alone as a binary (0) for those living alone, which represented $21 \%$ of respondents, as well as time spent per day (0-24 hours) on average socializing with others offline $(\mathrm{M}=3.5, \mathrm{SD}=4.1)$ and online $(\mathrm{M}=2.1 \mathrm{SD}=3.3)$. Lastly, a measure of sharing views on a strongly disagree - strongly agree scale operationalized the degree to which respondents felt that people around them share their views and interests $(\mathrm{M}=3.6, \mathrm{SD}=.85)$.

Control variables: Demographics were included as controls, and this sample had 516 males $(46.7 \%)$ and 589 females $(53.3 \%)$. The median age was 44 years $(M=45.19, \mathrm{SD}=$ 17.14). The income distribution had $26.2 \%$ respondents earning $\$ 24,999$ or less, $27.1 \%$ made between $\$ 25,000$ and $\$ 49,999$ as a household, $30.3 \%$ were in the $\$ 50,000$ to $\$ 99,999$ income bracket, and $16.4 \%$ reported earning $\$ 100,000$ or more annually. Along ethnic lines, $74.1 \%$ of respondents were Caucasian, 11.0\% were African American, 7.2\% were Hispanic/Latino, 5.2\% were Asian, $1.3 \%$ were Native American, $0.3 \%$ were Pacific Islanders, and $0.9 \%$ were of an 'other' ethnicity.

\section{Findings}

To begin, the regression models summarized in Table 1 provide an analysis of the first research question - if more frequent activity, passivity, or incivility on social media related to the likelihood of supporting a specific presidential candidate - and indicated some interesting 
patterns of self-reported voter preferences. Traditional media, especially newspapers (regardless print or online) demonstrated a minimal effect on the support of populist candidates. More interestingly, those that reported watching television for political information more frequently were more likely to support Clinton or Trump as their candidate, and to support Sanders or Cruz significantly less.

Among all the individual candidates, the likelihood of support for Trump was the most influenced by different social media usage patterns. American voters who used social media to actively participate in politics by posting their own thoughts and sharing or commenting on social media were actually more likely to not support Trump as a candidate. Yet, those who were more passive receivers of political information via social media were more likely (by 1.26 times) to support Trump as their preferred candidate. Similarly, those who reported being uncivil on social media were 1.90 times more likely to support Trump. There was a similar effect among Rubio supporters, where those that used social media for hostile purposes were 1.73 times more likely to support him.

Those that reported actively using social media for political purposes were most likely to support Kasich and Cruz (by 1.90 and 1.70 times, respectively) and less likely to support Clinton and Trump (by 0.73 and 0.77 times, respectively). Increased time spent on Facebook had a positive and significant effect on increasing the likelihood of supporting Carson, and decreased the likelihood of supporting either Kasich or Cruz. Perhaps counter to the prevailing narrative that has taken place in the wake of the election and inauguration of Trump (Benkler et al., 2017; Silverman, 2016), the amount of time respondents spent on Twitter had no statistically significant influence on individual vote preference. The summary of the findings reported thus far are compiled into Table 1. 
We turn now to examine RQ2 and to what extent higher levels of social media activity, passivity, and incivility related to an increased likelihood to generally support populist candidates, regardless if they were from the left or the right. Interestingly, our results indicate that, with some exception, the factors influencing the choice of more populist candidates are unique, or at least have different directions for supporting populist Democrats versus populist Republicans.

These analyses on an increased populist preference identified the influence of some similar variables that were observed among the models of individual candidate support. Staring here with demographics, ethnicity (being white) and having more conservative political views were strong positive predictors of choosing the more populist candidates for both Democrats and Republicans. The results are in line with the claim on specific role of the racial identity after the Obama's administration, which became "a more potent force in public opinion. Gaps between the political opinions of whites and blacks were frequently larger than they had been in the past" (Sides, Tesler, \& Vavreck, 2016, p. 52).

Yet on the contrary, party proximity (closer to Republicans) plays a role only for democratic populism, confirming that those with a more republican leaning would likely support Sanders over Clinton. The more politically knowledgeable respondents preferred democratic populism and were less likely to support republican populism.

In terms of media variables, more frequent television users were less likely to support democratic populism but more likely to endorse more populist candidates on Republican side, in the reported model by 1.27 times. The effect is reversed for radio audience (however without statistical significance for Democrats), and once again, the increased frequency of reading newspapers in any format is not significant. With specific attention to social media components of testing RQ2, those respondents who passively follow political information, or 
that were more uncivil on social media and spend more time on Facebook were more likely to support Republican populism.

Those who were politically active on social media were less likely to support Republican populism but were significantly more likely to support Democrat populism. These findings thereby contradict the idea of an ideological populist horseshoe of support, at least insofar as that support is mediated by differing forms of social media use. These results are summarized in Table 2.

-- Insert Table 2 about here --

Finally, in analyzing RQ3 and whether or not support for populist candidates was augmented by less heterogeneous online and offline communication networks. When measured as the increased frequency of discussing political or social issues with people representing different points of view (or of different origins), increased network heterogeneity demonstrated some interesting patterns of support. Specifically, those that reported more network diversity online were more likely to support Clinton (by 1.62 times) but those with greater diversity in offline conversations were significantly less likely to support her candidacy (by 0.73 times).

Since Clinton was the only candidate where online network heterogeneity was statistically significant there is almost no argument that can be made for online filter bubbles increasing support for more populist political candidates. In fact, having a diversified network of offline communication did result in increasing the likelihood of supporting populist political actors from the left and the right, namely Sanders and Carson, by 1.39 and 1.91 times, respectively. These results are found in Table 1.

Additionally, though not explicitly formalized into a separate research question, when investigating social media use factors that contributed to decreases in online and offline 
network heterogeneity (see Appendix A), we observed that social media use was not contributing directly or even indirectly to the creation of filter bubbles that have been reported elsewhere (Benkler et al., 2017; Silverman, 2016). Indeed, in our data, social media usage in terms of both format and time have significant effects on increasing, rather than decreasing network heterogeneity.

Those people who actively spend time on social media were more likely to have experiences with more diversified communicative network, both offline and online, and the effect holds regardless the amount of time spend on social media on general. Inversely, the interaction terms included in analysis show that those who passively spent substantially more time on social media during the campaign showed a network diversity that was noticeably diminished - in other words, they did not communicate often with others unlike them. Not surprisingly, those who tended toward uncivil behavior on social media were more likely to have diversified communication networks, however it must be taken into account that they build such networks with the intent to insult or enter into conflict situations than to carefully weigh or accept other points of view.

\section{Discussion and Conclusions}

Generally speaking, the results observed here align with previous research, on being active or passive within the online environment (Dimitrova et al., 2014; Kruikemeier et al., 2014). We add into the discussion here a possible relation that social media behavior may have on expressing support for populist political candidates. Those voters who actively participate in the social media environment, not only by reading but also by creating and sharing content, seems to have different patterns of support for populist candidates than those that are more passive receivers of political online content. Those active on social media are more likely to support Democratic populists than Republican populists, consequently those 
who were more active social media users were also less likely to have supported Trump as their candidate.

Alternately, those that were more passive social media users had a greater likelihood to support Republican populism in general, and Trump in particular. Similarly, those that reported being uncivil online were more likely to support populist Republicans on the whole and to prefer Trump more than any other candidate. Tracking such populist preferences in this campaign is revealing, and what we find here is that there was almost no support that online network homogeneity (our proxy for filter bubbles) was related to increasing the likelihood of increased support for populist political candidates. That finding also held to some extent of offline communicative networks, where greater heterogeneity (the opposite of filter bubbles) actually increased the likelihood of supporting Democratic populists, namely Sanders, and at least one Republican populist, specifically Carson. Otherwise there simply was no effect of network homogeneity (or heterogeneity) on populist political preference. Thus we do not find the confirmation of the argument that ideologically constrained flows of information would have been related to support for populist candidates (Benkler et al., 2017).

In addition, though not the focus of this study, our findings run counter to the argument that social media use was related to decreased network heterogeneity and the cultivation of filter bubbles in communication networks. We find quite the opposite effect for those that were more active or uncivil when using social media. This is to say that nearly all forms of social media use studied here - active, and uncivil as well as passive - were related to an increased likelihood of network heterogeneity for people talking politics both offline and online, where cross-cutting networks were apparent in our analyses.

From both theoretical and empirical standpoints, it is tempting but may be somewhat premature to suggest that social media is damaging democracy through filter bubbles or even 
that such bubbles are responsible for the growing wave of populism now evident in the US and elsewhere. Arguably, it could be considered that the diversity of viewpoints shared and the sheer volume of information circulated - factual, fake, or otherwise - has never been greater or reached a wider audience (Fenton, 2016; Hermida, 2014). The fact that increased reliance on traditional television as a news source related to an increased likelihood of supporting populist candidates on the right and decreased that likelihood on the left suggests that there is much more to individuals news consumption and candidate support than just social media use or filter bubbles alone.

Altogether, as we position these findings in a body of extant work that considers ideological horseshoes (van Elsas, Hakhverdian, \& van der Brug, 2016), it seems that support for populists was tempered by differing forms of social media and traditional media use, and almost certainly not homogenous communicative networks, especially those offline. While it cannot be disputed that social media was a central element in the campaign, and Trump's mode of Twitter-first public pronouncements may well have propelled him to victory, the evidence presented here is that it was not simply frequency of use, or even platform, but that vital aspects of digital and traditional journalism may have been lacking. As demonstrated elsewhere (Groshek \& Tandoc, 2017), a journalism of reciprocity has simply not evolved in a meaningful way, and that loosening of gatekeeping certainly opened the doors to a mediated information environment that while diverse and expansive was also hostile and prone to misinformation that may well have reinforced citizens' pre-existing viewpoints.

It would be erroneous to infer that all populists are ideological equivalent because the findings here suggest support of Democratic populists was in many cases the inverse of support for Republican populists. Those other factors, namely political knowledge, external efficacy, and type of social media activity will be crucial to better understand to more accurately predict elections in the future, and better gauge public opinion. Indeed, the 
democratic potential of mass self-communicators (Castells, 2007) may be inestimable, but the quality of democracy does not exist in a vacuum, and as this election and our results suggest, it now runs the risk of hostility being the basis of interactions and a civic media environment becoming both polluted and saturated with widely competing and unsubstantiated truth claims. Of course, the data analyzed here does not directly examine media content and is further limited by its cross-sectional design.

Still, the findings here do suggest that social media thus may have both directly and indirectly helped cultivate support populists in the primaries, but only in certain use cases that vary distinctly across political ideologies, and not explicitly through the mechanism of filter bubbles (Nelson, 2017). Perhaps it goes without saying at this stage, but social media almost certainly helped Trump with the election - with one caveat being it was not just social media content and campaigning but also a combination of television reliance, as well as passive and uncivil social media users that showed an increased likelihood of support within the broader milieu of a polarized political arena that was writ large in this campaign. 
Table 1. Logistic regression model of preferred individual candidate choice

\begin{tabular}{|c|c|c|c|c|c|c|c|c|c|c|c|c|c|c|}
\hline $\begin{array}{l}\text { Candidates } \\
\text { Populism level }\end{array}$ & \multicolumn{2}{|c|}{$\begin{array}{c}\text { Clinton } \\
(0.58)\end{array}$} & \multicolumn{2}{|c|}{$\begin{array}{l}\text { Sanders } \\
(1.22)\end{array}$} & \multicolumn{2}{|c|}{$\begin{array}{l}\text { Kasich } \\
(0.24)\end{array}$} & \multicolumn{2}{|c|}{$\begin{array}{l}\text { Carson } \\
(0.60)\end{array}$} & \multicolumn{2}{|c|}{$\begin{array}{l}\text { Rubio } \\
(0.49)\end{array}$} & \multicolumn{2}{|c|}{$\begin{array}{l}\text { Cruz } \\
(0.25)\end{array}$} & \multicolumn{2}{|c|}{$\begin{array}{l}\text { Trump } \\
(0.66)\end{array}$} \\
\hline \multicolumn{15}{|l|}{ Socio-demographics } \\
\hline Age & 1.008 & $*$ & .982 & $* * *$ & 1.021 & $*$ & 1.000 & & 1.003 & & 1.000 & & 1.003 & \\
\hline Gender & 1.037 & & 1.125 & & 1.063 & & 1.726 & $* *$ & 1.004 & & .823 & & .665 & $* *$ \\
\hline Income & .901 & & 1.139 & $*$ & 1.366 & & .973 & & .886 & & 1.020 & & .941 & \\
\hline Education & 1.156 & $* *$ & .956 & & 1.250 & $*$ & .985 & & 1.105 & & .884 & & .925 & \\
\hline Ethnicity & .479 & $* * *$ & 1.825 & $* * *$ & 1.878 & & .622 & $* *$ & .561 & $* *$ & .686 & & 2.540 & $* * *$ \\
\hline \multicolumn{15}{|l|}{ Political characteristics } \\
\hline Party proximity (Rep) & .454 & $* * *$ & 1.332 & $*$ & .515 & & 1.304 & & 2.804 & $* * *$ & 1.166 & & 1.205 & \\
\hline Political ideology & .762 & $* * *$ & .944 & & .667 & $* * *$ & 1.135 & $* *$ & .945 & & 1.290 & $* *$ & 1.138 & $* *$ \\
\hline Political knowledge & .857 & $* *$ & 1.047 & & 1.145 & & 1.031 & & 1.403 & $* *$ & .936 & & .870 & $* *$ \\
\hline Voting habits & .989 & & .986 & & 1.052 & & 1.100 & & .931 & & .929 & & .885 & $* *$ \\
\hline Internal efficacy & .943 & & .937 & & 1.226 & & .826 & & .800 & & .969 & & .862 & \\
\hline External efficacy & 1.051 & & 1.020 & & 1.097 & & 1.264 & $* *$ & 1.072 & & 1.129 & & .803 & $* *$ \\
\hline Life satisfaction & 1.035 & & .971 & & 1.000 & & .967 & & 1.088 & $*$ & 1.061 & & 1.042 & \\
\hline Trust in others & 1.142 & & .921 & & .689 & $*$ & .969 & & .940 & & 1.025 & & .908 & \\
\hline \multicolumn{15}{|l|}{ Network heterogeneity } \\
\hline Offline network & .728 & $*$ & 1.393 & $*$ & 1.386 & & 1.910 & $* *$ & 1.193 & & 670 & & .817 & \\
\hline Online network & 1.615 & $* *$ & .824 & & .919 & & .877 & & .597 & & 1.027 & & 1.059 & \\
\hline \multicolumn{15}{|c|}{ Media usage for political purposes } \\
\hline Radio & .851 & $*$ & 1.016 & & .837 & & .977 & & 1.032 & & 1.901 & $* * *$ & .882 & \\
\hline Television & 1.506 & $* * *$ & .834 & $* *$ & .986 & & 1.051 & & 1.216 & & .773 & $*$ & 1.443 & $*$ \\
\hline Newspapers print & 1.107 & & 1.003 & & 1.059 & & 1.017 & & .969 & & 1.034 & & 1.069 & \\
\hline Newspapers online & .993 & & 1.020 & & .982 & & 1.153 & & .973 & & .687 & $* *$ & .871 & \\
\hline \multicolumn{15}{|l|}{ Social media usage } \\
\hline Social media active & .730 & $* *$ & 1.220 & & 1.896 & $* *$ & 1.002 & & 1.000 & & 1.702 & $* *$ & .771 & $*$ \\
\hline Social media passive & 1.160 & & .858 & & .851 & & .815 & & .948 & & .919 & & 1.260 & * \\
\hline Social media incivility & .885 & & .961 & & .733 & & .784 & & 1.726 & $*$ & .695 & & 1.903 & $* *$ \\
\hline Time spent on Facebook & .990 & & 1.004 & & .823 & $* *$ & 1.052 & $* *$ & .953 & & .925 & * & .992 & \\
\hline Time spent on Twitter & .986 & & .976 & & .814 & & .956 & & 1.050 & & .936 & & 1.061 & \\
\hline Constant & .838 & & 1.708 & & .006 & $* * *$ & .060 & $* * *$ & .029 & $* * *$ & .039 & $* * *$ & .357 & $*$ \\
\hline Log likelihood & -653.2 & & -681 & & -158. & 801 & -430.3 & 361 & -313 & 438 & -251 & & -562 & 104 \\
\hline
\end{tabular}

Note: Odds ratios reported for logistic regression; $\mathrm{N}=1105 ;{ }^{*} \mathrm{p}<.1,{ }^{*} \mathrm{p}<.05,{ }^{*} * \mathrm{p}<.001$. The scale of populism is employed after (Oliver \& Rahn, 2016) and is explained in the methodological section with more detail. 
Table 2. Ordered logistic regression model of support for increasingly populist candidates

$$
\text { Democratic Populists Republican Populists }
$$

\begin{tabular}{|c|c|c|c|c|}
\hline Socio-demographics & & & & \\
\hline Age & .986 & $* *$ & .997 & \\
\hline Gender & 1.059 & & .797 & \\
\hline Income & 1.147 & & .926 & \\
\hline Education & .885 & $* *$ & .929 & \\
\hline Ethnicity & 2.105 & $* * *$ & 1.751 & $* *$ \\
\hline Political characteristics & & & & \\
\hline Party proximity (Rep) & 1.942 & $* *$ & .972 & \\
\hline Political ideology & 1.145 & $* *$ & 1.121 & $* *$ \\
\hline Political knowledge & 1.139 & $* *$ & .849 & $* *$ \\
\hline Voting habits & 1.021 & & .948 & \\
\hline Internal efficacy & 1.017 & & .878 & \\
\hline External efficacy & .990 & & .802 & $* *$ \\
\hline Life satisfaction & .966 & & .984 & \\
\hline Trust in others & .868 & & .991 & \\
\hline Network heterogeneity & & & & \\
\hline Offline network & 1.429 & $*$ & .859 & \\
\hline Online network & .697 & & 1.097 & \\
\hline Media usage for political & & & & \\
\hline Radio & 1.117 & & .824 & $* *$ \\
\hline Television & .686 & $* * *$ & 1.273 & $* *$ \\
\hline Newspapers print & .926 & & 1.055 & \\
\hline Newspapers online & 1.021 & & .971 & \\
\hline Social media usage & & & & \\
\hline Social media active & 1.361 & $* *$ & .671 & $* *$ \\
\hline Social media passive & .845 & & 1.274 & $*$ \\
\hline Social media incivility & .979 & & 1.573 & $* *$ \\
\hline Time spent on Facebook & 1.003 & & 1.048 & $* *$ \\
\hline Time spent on Twitter & .983 & & 1.042 & \\
\hline $\begin{array}{l}\text { Log likelihood } \\
\mathrm{N}\end{array}$ & $\begin{array}{r}20854 \\
887\end{array}$ & & $\begin{array}{c}-906.228 \\
660\end{array}$ & \\
\hline
\end{tabular}

Note: Ordered logistic regression (logistic for Democrats); ${ }^{*} \mathrm{p}<.1, * * \mathrm{p}<.05, * * * \mathrm{p}<.001$. The scale of populism is employed after (Oliver \& Rahn, 2016) and is explained in the methodological section with more detail. 
Social Media Use, Network Heterogeneity, and Support for Populists 24

\section{References}

Akkerman, A., Mudde, C., \& Zaslove, A. (2014). How Populist Are the People? Measuring Populist Attitudes in Voters. Comparative Political Studies, 47(9), 1324-1353. https://doi.org/10.1177/0010414013512600

Baer, D. (2016). The "Filter Bubble" Explains Why Trump Won and You Didn't See It Coming. Retrieved December 12, 2016, from http://nymag.com/scienceofus/2016/11/how-facebook-and-the-filter-bubble-pushedtrump-to-victory.html

Bakker, B. N., Rooduijn, M., \& Schumacher, G. (2016). The psychological roots of populist voting: Evidence from the United States, the Netherlands and Germany: THE PSYCHOLOGICAL ROOTS OF POPULIST VOTING. European Journal of Political Research, 55(2), 302-320. https://doi.org/10.1111/1475-6765.12121

Bakker, T. P., \& de Vreese, C. H. (2011). Good News for the Future? Young People, Internet Use, and Political Participation. Communication Research, 38(4), 451-470. https://doi.org/10.1177/0093650210381738

Bakshy, E., Messing, S., \& Adamic, L. A. (2015). Exposure to ideologically diverse news and opinion on Facebook. Science, 348(6239), 1130-1132. https://doi.org/10.1126/science.aaa1160

Bartels, L. M. (2016). Elections in America. The ANNALS of the American Academy of Political and Social Science, 667(1), 36-49. https://doi.org/10.1177/0002716216662035

Benkler, Y., Faris, R., Roberts, H., \& Zuckerman, E. (2017). Study: Breitbart-led right-wing media ecosystem altered broader media agenda. Retrieved March 7, 2017, from http://www.cjr.org/analysis/breitbart-media-trump-harvard-study.php 
Bimber, B. (2014). Digital Media in the Obama Campaigns of 2008 and 2012: Adaptation to the Personalized Political Communication Environment. Journal of Information Technology \& Politics, 11(2), 130-150.

https://doi.org/10.1080/19331681.2014.895691

Boulianne, S. (2009). Does Internet Use Affect Engagement? A Meta-Analysis of Research. Political Communication, 26(2), 193-211. https://doi.org/10.1080/10584600902854363

Boulianne, S. (2015). Social media use and participation: a meta-analysis of current research. Information, Communication \& Society, 18(5), 524-538. https://doi.org/10.1080/1369118X.2015.1008542

Castells, M. (2007). Communication, Power and Counter-power in the Network Society. International Journal of Communication, 1, 238-266.

Ceron, A., \& dAdda, G. (2016). E-campaigning on Twitter: The effectiveness of distributive promises and negative campaign in the 2013 Italian election. New Media \& Society, 18(9), 1935-1955. https://doi.org/10.1177/1461444815571915

Colleoni, E., Rozza, A., \& Arvidsson, A. (2014). Echo Chamber or Public Sphere? Predicting Political Orientation and Measuring Political Homophily in Twitter Using Big Data: Political Homophily on Twitter. Journal of Communication, 64(2), 317-332. https://doi.org/10.1111/jcom.12084

Dimitrova, D. V., Shehata, A., Strömbäck, J., \& Nord, L. W. (2014). The Effects of Digital Media on Political Knowledge and Participation in Election Campaigns: Evidence From Panel Data. Communication Research, 41(1), 95-118. https://doi.org/10.1177/0093650211426004

El-Bermawy, M. (2016). Your Filter Bubble is Destroying Democracy. Retrieved December 12, 2016, from https://www.wired.com/2016/11/filter-bubble-destroying-democracy/ 
Engesser, S., Ernst, N., Esser, F., \& Büchel, F. (2016). Populism and social media: how politicians spread a fragmented ideology. Information, Communication \& Society, 118. https://doi.org/10.1080/1369118X.2016.1207697

Ernst, N., Engesser, S., \& Esser, F. (2016). Switzerland. Favorable conditions for growing populism. (T. Aalberg, F. Esser, C. Reinemann, J. Stromback, \& C. H. De Vreese, Eds.) (Populist Political Communication in Europe, Vol. Populist Political Communication in Europe). Routledge. https://doi.org/10.4324/9781315623016

Fawzi, N., Obermaier, M., \& Reinemann, C. (2016). Germany. Is the populism laggard catching up? (T. Aalberg, F. Esser, C. Reinemann, J. Stromback, \& C. H. De Vreese, Eds.). Routledge. https://doi.org/10.4324/9781315623016

Fenton, N. (2016). The internet of me (and my 'friends'). Misinformation and the internet (J. Curran, N. Fenton, D. Freedman, Eds.). Routledge. ISBN: 978-1-315-69562-4

Flaxman, S., Goel, S., \& Rao, J. M. (2013). Ideological Segregation and the Effects of Social Media on News Consumption. SSRN Electronic Journal. https://doi.org/10.2139/ssrn.2363701

Gidengil, E., Hennigar, M., Blais, A., \& Nevitte, N. (2005). Explaining The Gender Gap in Support for the New Right: The Case of Canada. Comparative Political Studies, 38(10), 1171-1195. https://doi.org/10.1177/0010414005279320

Gil de Zúñiga, H., Garcia-Perdomo, V., \& McGregor, S. C. (2015). What Is Second Screening? Exploring Motivations of Second Screen Use and Its Effect on Online Political Participation: Second Screen Use \&amp; Online Political Participation. Journal of Communication, 65(5), 793-815. https://doi.org/10.1111/jcom.12174

Groshek, J., \& Cutino, C. (2016). Meaner on Mobile: Incivility and Impoliteness in Communicating Contentious Politics on Sociotechnical Networks. Social Media + Society, 2(4). https://doi.org/10.1177/2056305116677137 
Groshek, J., \& Engelbert, J. (2013). Double differentiation in a cross-national comparison of populist political movements and online media uses in the United States and the Netherlands. New Media \& Society, 15(2), 183-202. https://doi.org/10.1177/1461444812450685

Groshek, J, \& Dimitrova, D. (2013). A Cross-Section of Political Involvement, Partisanship and Online Media in Middle America During the 2008 Presidential Campaign. Atlantic Journal of Communication, 21(2), 108-124. https://doi.org/10.1080/15456870.2013.773484

Groshek, J, \& Tandoc, E. (2017). The affordance effect: Gatekeeping and (non)reciprocal journalism on Twitter. Computers in Human Behavior, 66, 201-210. https://doi.org/10.1016/j.chb.2016.09.020

Halpern, D., \& Gibbs, J. (2013). Social media as a catalyst for online deliberation? Exploring the affordances of Facebook and YouTube for political expression. Computers in Human Behavior, 29(3), 1159-1168. https://doi.org/10.1016/j.chb.2012.10.008

Hermida, A. (2014). Tell everyone: Why we share and why it matters. Doubleday.

Hmielowski, J. D., Hutchens, M. J., \& Cicchirillo, V. J. (2014). Living in an age of online incivility: examining the conditional indirect effects of online discussion on political flaming. Information, Communication \& Society, 17(10), 1196-1211. https://doi.org/10.1080/1369118X.2014.899609

Hooton, J. (2016, November 10). Your social media echo chamber is the reason Donald Trump ended up being voted President. Retrieved December 11, 2016, from http://www.independent.co.uk/voices/donald-trump-president-social-media-echochamber-hypernormalisation-adam-curtis-protests-blame-a7409481.html

Isaac, M. (2016, November 12). Facebook, in Cross Hairs After Election, Is Said to Question Its Influence. The New York Times. Retrieved from 
Social Media Use, Network Heterogeneity, and Support for Populists 28

http://www.nytimes.com/2016/11/14/technology/facebook-is-said-to-question-itsinfluence-in-election.html

Isaac, M., \& Ember, S. (2016, November 8). For Election Day Influence, Twitter Ruled Social Media. The New York Times. Retrieved from http://www.nytimes.com/2016/11/09/technology/for-election-day-chatter-twitterruled-social-media.html

Jagers, J., \& Walgrave, S. (2007). Populism as political communication style: An empirical study of political parties' discourse in Belgium. European Journal of Political Research, 46(3), 319-345. https://doi.org/10.1111/j.1475-6765.2006.00690.x

Klinger, U., \& Svensson, J. (2015). The emergence of network media logic in political communication: A theoretical approach. New Media \& Society, 17(8), 1241-1257. https://doi.org/10.1177/1461444814522952

Koopmans, R., \& Muis, J. (2009). The rise of right-wing populist Pim Fortuyn in the Netherlands: A discursive opportunity approach. European Journal of Political Research, 48(5), 642-664. https://doi.org/10.1111/j.1475-6765.2009.00846.x

Krastev, I. (2007). The populist moment. Retrieved December 11, 2016, from http://www.eurozine.com/articles/2007-09-18-krastev-en.html

Kruikemeier, S., van Noort, G., Vliegenthart, R., \& de Vreese, C. H. (2014). Unraveling the effects of active and passive forms of political Internet use: Does it affect citizens' political involvement? New Media \& Society, 16(6), 903-920. https://doi.org/10.1177/1461444813495163

Maruyama, M., Robertson, S. P., Douglas, S., Semaan, B., \& Faucett, H. (2014). Hybrid Media Consumption: How Tweeting During a Televised Political Debate Influences the Vote Decision. Presented at the Paper presented at ACM Conference on Computer Supported Cooperative Work (CSCW 2014). Baltimore, MD. New York: ACM. 
McCormick, R. (2016a, November 13). Donald Trump says Facebook and Twitter 'helped him win'. The Verge. Retrieved from http://www.theverge.com/2016/11/13/13619148/trump-facebook-twitter-helped-win

McCormick, R. (2016b, November 10). Mark Zuckerberg sidesteps blame for Trump presidency, says we should all 'work harder'. The Verge. Retrieved from http://www.theverge.com/2016/11/10/13582008/mark-zuckerberg-facebook-trumppresident-statement

McKenzie, F. (2016, November 19). The Secret Agenda of a Facebook Quiz. The New York Times. Retrieved from http://www.nytimes.com/2016/11/20/opinion/the-secretagenda-of-a-facebook-quiz.html

Miconi, A. (2015). Italy’s “Five Stars" movement and the role of a leader: Or, how charismatic power can resurface through the web. New Media \& Society, 17(7), 10431058. https://doi.org/10.1177/1461444814520872

Moffitt, B., \& Tormey, S. (2014). Rethinking Populism: Politics, Mediatisation and Political Style: Rethinking Populism. Political Studies, 62(2), 381-397. https://doi.org/10.1111/1467-9248.12032

Muller, J.-W. (2016). What Is Populism? Philadelphia: University of Pennsylvania Press. Nelson, J. (2017). Is 'fake news' a fake problem? Columbia Journalism Review. Retrieved from http://www.cjr.org/analysis/fake-news-facebook-audience-drudge-breitbartstudy.php

Oliver, J. E., \& Rahn, W. M. (2016). Rise of the Trumpenvolk: Populism in the 2016 Election. The ANNALS of the American Academy of Political and Social Science, 667(1), 189-206. https://doi.org/10.1177/0002716216662639 
Pagani, M., Hofacker, C. F., \& Goldsmith, R. E. (2011). The influence of personality on active and passive use of social networking sites. Psychology and Marketing, 28(5), 441-456. https://doi.org/10.1002/mar.20395

Parkinson, H. (2016, November 14). Click and elect: how fake news helped Donald Trump win a real election. The Guardian. Retrieved from https://www.theguardian.com/commentisfree/2016/nov/14/fake-news-donald-trumpelection-alt-right-social-media-tech-companies

Rooduijn, M. (2014). The Mesmerising Message: The Diffusion of Populism in Public Debates in Western European Media: The Mesmerising Message. Political Studies, 62(4), 726-744. https://doi.org/10.1111/1467-9248.12074

Sides, J., Tesler, M., \& Vavreck, L. (2016). The Electoral Landscape of 2016. The ANNALS of the American Academy of Political and Social Science, 667(1), 50-71. https://doi.org/10.1177/0002716216658922

Silverman, C. (2016). This analysis shows how viral fake election news stories outperformed real news on Facebook. Retrieved from https://www.buzzfeed.com/craigsilverman/viral-fake-election-news-outperformedreal-news-on-facebook?utm_term=.yjaky1Omp\#.qi7z4ybq8

Skoric, M. M., Zhu, Q., Goh, D., \& Pang, N. (2016). Social media and citizen engagement: A meta-analytic review. New Media \& Society, 18(9), 1817-1839. https://doi.org/10.1177/1461444815616221

Spruyt, B., Keppens, G., \& Van Droogenbroeck, F. (2016). Who Supports Populism and What Attracts People to It? Political Research Quarterly, 69(2), 335-346. https://doi.org/10.1177/1065912916639138 
Strandberg, K. (2015). A social media revolution or just a case of history repeating itself? The use of social media in the 2011 Finnish parliamentary elections. New Media \& Society, 15(8), $1329-1347$.

Trudel, D. (2016). L'élection de Trump dans l'oeil de l'École de Francfort. Le Devoir. Retrieved from http://www.ledevoir.com/societe/le-devoir-de-philo/486824/le-devoirde-philo-l-election-de-trump-dans-1-oeil-de-l-ecole-de-francfort

van der Brug, W., \& Mughan, A. (2007). Charisma, Leader Effects and Support for RightWing Populist Parties. Party Politics, 13(1), 29-51. https://doi.org/10.1177/1354068806071260

van Elsas, E. J., Hakhverdian, A., \& van der Brug, W. (2016). United against a common foe? The nature and origins of Euroscepticism among left-wing and right-wing citizens. West European Politics, 39(6), 1181-1204. https://doi.org/10.1080/01402382.2016.1175244

Vezzoni, C., \& Mancosu, M. (2016). Diffusion Processes and Discussion Networks: An Analysis of the Propensity to Vote for the 5 Star Movement in the 2013 Italian Election. Journal of Elections, Public Opinion and Parties, 26(1), 1-21. https://doi.org/10.1080/17457289.2015.1102145

Xenos, M., Vromen, A., \& Loader, B. D. (2014). The great equalizer? Patterns of social media use and youth political engagement in three advanced democracies. Information, Communication \& Society, 17(2), 151-167. https://doi.org/10.1080/1369118X.2013.871318 
Social Media Use, Network Heterogeneity, and Support for Populists 32

Appendix A: Ordered logistic regression model for network heterogeneity offline and online

Offline network Online network

\begin{tabular}{|c|c|c|c|c|}
\hline \multicolumn{5}{|l|}{ Socio-demographics } \\
\hline Age & .991 & $* *$ & .988 & $* *$ \\
\hline Gender & .698 & $* *$ & .508 & $* * *$ \\
\hline Income & 1.091 & & .983 & \\
\hline Education & 1.103 & $*$ & 1.054 & \\
\hline Ethnicity & 1.147 & & 1.130 & \\
\hline \multicolumn{5}{|l|}{ Socialization } \\
\hline Closeness with others & 1.033 & & 1.029 & \\
\hline Living alone & .850 & & .877 & \\
\hline Time socializing offline & 1.032 & & .998 & \\
\hline Time socializing online & 1.069 & $*$ & 1.119 & $* *$ \\
\hline Sharing views & 1.158 & & 1.159 & \\
\hline \multicolumn{5}{|l|}{ Political characteristics } \\
\hline Political ideology & 1.003 & & .876 & $* *$ \\
\hline Political knowledge & 1.127 & $* *$ & 1.088 & \\
\hline Life satisfaction & 1.018 & & .990 & \\
\hline Trust in others & 1.199 & $* *$ & 1.160 & \\
\hline \multicolumn{5}{|l|}{ Social media usage } \\
\hline Social media active & 2.140 & $* * *$ & 2.896 & $* * *$ \\
\hline Social media passive & 1.855 & $* * *$ & 2.094 & $* * *$ \\
\hline Time spent on social media & .938 & $* *$ & .955 & \\
\hline SM time * Active SM & 1.024 & & 1.047 & \\
\hline SM time * Passive SM & .955 & $* *$ & .945 & $* *$ \\
\hline Social media incivility & 1.621 & $* *$ & 1.565 & $* *$ \\
\hline Log likelihood & -1054.356 & & -776.931 & \\
\hline
\end{tabular}

Note: Ordered logistic regression; $\mathrm{N}=1105 ;{ }^{*} \mathrm{p}<.1, * * \mathrm{p}<.05, * * * \mathrm{p}<.001$ 